\title{
Subsistence use of fallow vegetation in the highlands of Papua New Guinea
}

\author{
B. T. M. Louman (Department of Silviculture and Forest Ecology, Wageningen \\ Agricultural University, P.O. Box 342, NL 6700 AA Wageningen, Netherlands)
}

Received 13 October 1986; accepted 30 July 1987

\begin{abstract}
Investigation into the structural and floristic composition of fallow vegetations in the Wau area in Papua New Guinea at different time intervals after last cultivation confirms the general ideas of secondary succession, and verifies the theoretical model of ecologically sound land-use described by Oldeman (1983a).
\end{abstract}

Key words: Papua New Guinea, fallow vegetation, secondary succession, subsistence use, selective plant use, deflected succession

Introduction. In a theoretical model, Oldeman (1983a) proposes that a vegetation can be managed in such a way that natural components with agricultural, forestral, or other importance are favoured. Useful ecological analogues of natural components without such importance may be introduced. The resulting vegetation should show a development similar to the local, spontaneously developing secondary vegetation. The present study is an attempt to link Oldeman's model to the (traditional) practice of the Biangai people, living in villages south-east of Wau town, at approximately $7^{\circ} 25^{\prime \prime} \mathrm{S}, 146^{\circ} 42^{\prime \prime} \mathrm{E}$ and an altitude of 1000 to $1200 \mathrm{~m}$. They mainly live from shifting cultivation practices, maintaining long tree fallows.

Method. Based on the information of local informants, ten study sites were selected. Two sites had been cultivated 5 to 8 years ago, two 8 to 12 years ago, and two 15 to 20 years ago. Other sites had been subjected to frequent fires, lit for clearing purposes, of which the last ones had occurred less than one (1 field), five (1 field), and 20 years ago (2 fields). Sites varied in size from $100 \mathrm{~m}^{2}$ to $500 \mathrm{~m}^{2}$, according to the extent of the cultivated surfaces. Climate and chemical soil fertility were approximately homogeneous over the studied area. Transects were marked, profile diagrams drawn, and data recorded, according to the method described by Oldeman (1983b). A reconstruction of the fallow cycle and its use by man has been attempted (Fig. 1), combining data obtained from the profile diagrams with site histories.

Results. The first one to two years after clearing, tuberous crops, viny crops, and large herbs are cultivated, while woody seedlings of genera such as Macaranga (Euphorbiaceae), Trichospermum (Tiliaceae), and Lithocarpus (Fagaceae) may be tol- 
erated. In the second year grasses and ferns have infiltrated the garden to such an extent that the area is left to spontaneous regrowth for 10 to 12 years (Fig. 1A). During the latter period the main human activity is the extraction of firewood and of some medicinal plants (e.g. Zingiberaceae). Cutting of shrubs such as Macaranga sp. and Acalypha sp. (Euphorbiaceae) creates environments that are favourable to herbs and seedlings. Regrowth may continue beyond 12 years. In such regrowth selective harvesting takes place of plants used for construction purposes, tool handles, or weapons (e.g. Dysoxylum spp., Aglaia spp. (Meliaceae) and Calamus spp. (Palmae) respectively). Selective harvesting in its turn creates one-tree gaps, favouring other useful plants: encountered concentrations of vines (tying purposes), grasses and Zingiberaceae (medicinal purposes), and the occurrence of fruit trees were due to these practices. It may, however, also set in motion successional processes that favour individuals of a later phase (e.g. Elmerillia sp. (Magnoliaceae)) (sc in Fig. 1A).

Villagers consider a regrowth period of 10 to 12 years sufficient to restore the capacity of the site to produce crops. Often clear-cutting takes place at that time, after which the fallow cycle recommences with cultivation. Sometimes trees are left standing, though pollarded. Then succession is not completely interrupted, and after cultivation, regrowth occurs underneath an open canopy. Two of these latter sites were studied 15 to 20 years after recultivation. They had attained a tree stand with a basal area (trees with a diameter at $1.30 \mathrm{~m}$ of more than $10 \mathrm{~cm}$ ) of approximately $0.4 \mathrm{~m}^{2}$ per $100 \mathrm{~m}^{2}$, with densities of 4 to 6 trees per $100 \mathrm{~m}^{2}$ (Lithocarpus sp., Elmerillia sp., and Dysoxylum sp.). These figures are similar to those of natural regeneration in a tropical, lower montane forest area in Papua New Guinea as described by Paijmans (1976).

The frequent occurrence of uncontrolled fires in any phase of the cycle described above causes a deflected succession (Fig. 1B), which reduces the availability of useful plant species. This has been realized by the villagers, and regrowth on land that has been protected from fires for 20 years, shows that occurring deflections were not yet irreversible (Fig. 1C).

Discussion. With the exception of uncontrolled fires, the traditional practices of the Biangai people seem to enable practicing a sustained management of an area with simultaneous:

1) use of small areas for gardening;

2) extraction of materials from the vegetation for subsistence requirements;

3) growth of a considerable quantity of timber trees;

4) maintenance of a vegetation in which processes occur that resemble the local natural processes.

These traditional practices seem to support the model of Oldeman (1983a). However, insufficient sites were studied to obtain complete data on the effects of subsistence use upon the development of the fallow vegetation in the Wau area. 
B. T. M. LOUMAN

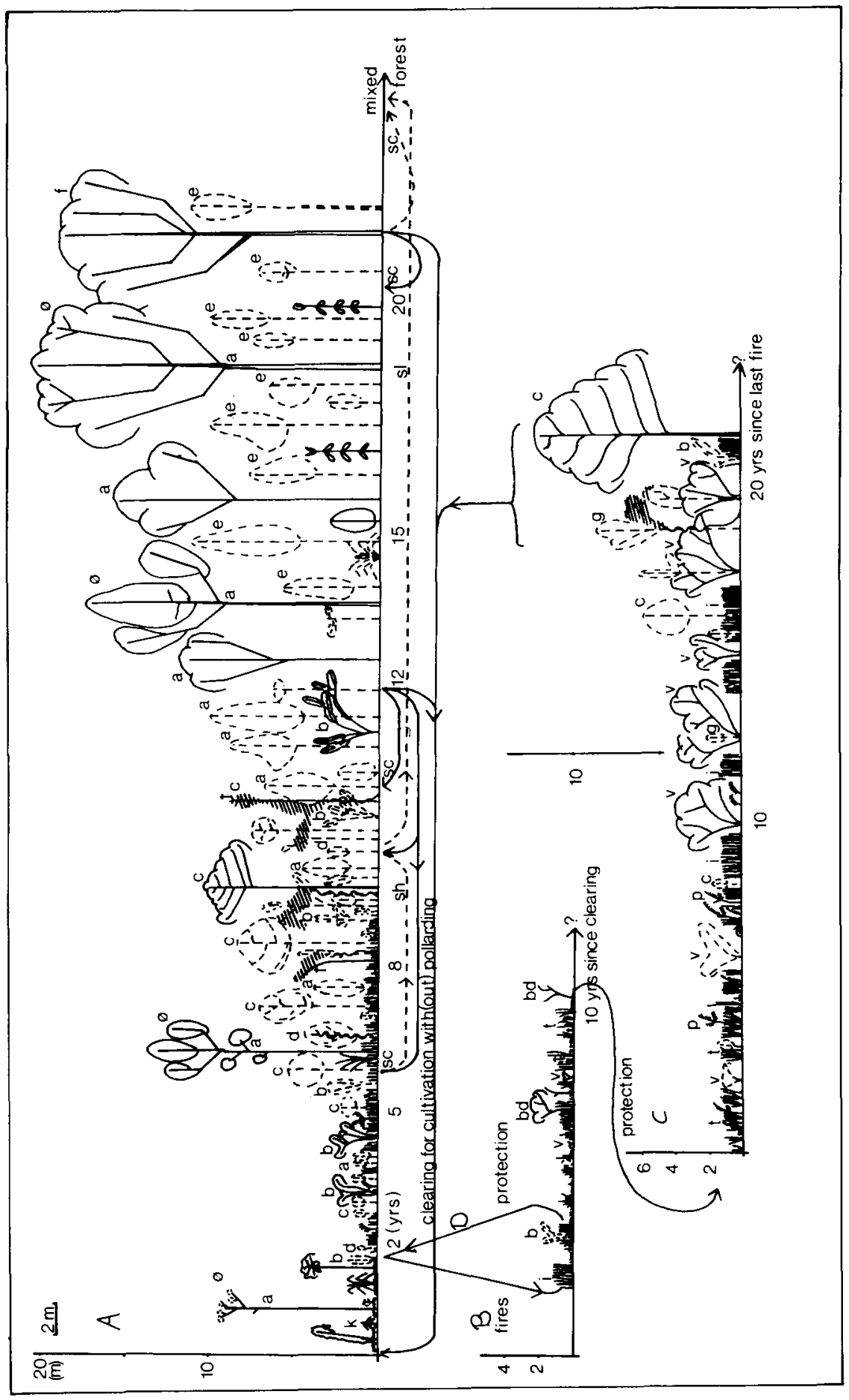


Fig. 1. Development of a fallow vegetation near Wau in the highlands of Papua New Guinea.

A. Traditional cultivation followed by secondary regrowth for over 20 years. Solid lines with arrows: regrowth interrupted by cutting of (selected) plants, resulting in a return to an earlier development phase. Dotted lines with arrows: alternative development courses in which one or more phases may be skipped, due to shallow soils (sh), different seed sources and/or selection criteria (sl) or to selective cutting (sc). Within the encountered mixed forest patches species occurred, such as Elmerillia papuana (Magnoliaceae), Dysoxylum spp. (Meliaceae), and Syzygium spp. (Myrtaceae).

$\mathrm{a}=$ Lithocarpus sp. (Fagaceae), $\mathrm{b}=$ Acalypha sp. (Euphorbiaceae), $\mathrm{c}=$ Trichospermum pleiostigma (Tiliaceae), $\mathrm{d}=$ Macaranga sp. (Euphorbiaceae), $\mathrm{e}=$ young, developing trees. Genera encountered with local importance were Dysoxylum, Aglaia (Meliaceae) and Calamus (Palmae), $\mathrm{f}=$ Elmerillia papuana (Magnoliaceae), $\mathrm{k}=$ garden with Dioscorea spp. (Dioscoreaceae), Ipomoea batatas (Convolvulaceae), Carica papaya (Caricaceae), Saccharum spp., (Gramineae), $\emptyset=$ pollarded tree, $/ / / I=$ lianas.

B. After cultivation fires may occur. If not for longer than for one or two years, development will follow the general lines of A (arrow D). After regular burning (i.e. once or more times every year) vegetation will develop as shown in $\mathrm{B}$.

bd $=$ Banksia dentata $($ Proteaceae), $\mathrm{i}=$ Imperata cylindrica (Gramineae), $\mathrm{t}=$ Themeda australis (Gramineae), $v=$ Vaccinium $\mathrm{sp}$. (Ericaceae).

C. Does protection from fire start after a Themeda-grassland has developed, a vegetation develops which is probably adjusted to drier conditions. Cultivation in the twentieth year of protection is said to start a cycle as in $\mathrm{A}$.

$\mathrm{g}=$ Grevillea $\mathrm{sp}$. (Proteaceae), $\mathrm{p}=$ Pteridium aquilinum (Denstaedtiaceae).

What happens if fires continue to occur for more than 10 years is not known for the area. Nor is know how the vegetation in part $\mathrm{C}$ will develop if it is left to grow spontaneously for over 20 years (question marks in $B$ and $C$ ).

All arrows: directions of possible developments.

\section{References}

Oldeman, R. A. A., 1983a. The design of ecologically sound agroforests. In: P. A. Huxley (ed.), Plant research and agroforestry, p. 173-207. International Councel for Research in AgroForestry, Nairobi..

Oldeman, R. A. A., 1983b. Veldgids transecttekenen (Field guide to the drawing of transects). Department of Silviculture, Wageningen Agricultural University.

Paijmans, K. (ed.), 1976. New Guinea vegetation. Commonwealth Scientific and Industrial Research Organisation \& Australian National University Press, Canberra..

This synopsis is based on un undergraduate thesis 'Structural and floristic composition of a Lithocarpus fallow in Papua New Guinea' by Bas T. Louman, Department of Silviculture, Wageningen Agricultural University, 1986. 52 pp., 17 figs., 20 tables, 39 refs., 1 appendix.

Available as paper copy (order R076P, $f 20$ including postage) or microfiche (order R076M, f 12.50 including postage) at: NARD, clo Pudoc, P.O. Box 4, 6700 AA Wageningen, Netherlands (telex 45015 blhwg). 